University of Nebraska - Lincoln

DigitalCommons@University of Nebraska - Lincoln

Faculty Papers and Publications in Animal

Science

Animal Science Department

1980

\title{
Effect of Lactobacillus Acidophilus on Starter Pigs Fed a Diet Supplemented with Lactose
}

\author{
D. S. Pollmann \\ University of Nebraska-Lincoln \\ D. M. Danielson \\ University of Nebraska-Lincoln \\ E. R. Peo, Jr. \\ University of Nebraska-Lincoln
}

Follow this and additional works at: https://digitalcommons.unl.edu/animalscifacpub

Part of the Animal Sciences Commons

Pollmann, D. S.; Danielson, D. M.; and Peo, Jr., E. R., "Effect of Lactobacillus Acidophilus on Starter Pigs Fed a Diet Supplemented with Lactose" (1980). Faculty Papers and Publications in Animal Science. 648. https://digitalcommons.unl.edu/animalscifacpub/648

This Article is brought to you for free and open access by the Animal Science Department at DigitalCommons@University of Nebraska - Lincoln. It has been accepted for inclusion in Faculty Papers and Publications in Animal Science by an authorized administrator of DigitalCommons@University of Nebraska - Lincoln. 


\title{
EFFECT OF LACTOBACILLUS ACIDOPHILUS ON STARTER PIGS FED A DIET SUPPLEMENTED WITH LACTOSE ${ }^{1}$
}

\author{
D. S. Pollmann, D. M. Danielson and E. R. Peo, Jr. \\ University of Nebraska ${ }^{2}$, Lincoln 68583
}

\begin{abstract}
Summary
Seventy-two crossbred pigs (average initial weight $6 \mathrm{~kg}$ ) were used to study the effect of L. acidophilus (lactic acid-producing bacteria common in probiotics) in starter diets on gain, feed conversion, fecal lactobacillus and coliform counts, hematology and serum proteins. The nonmedicated experimental diets were corn-soybean meal ( $18 \%$ crude protein) diets with two levels of lactose ( 0 and $10 \%)$. It has been theorized that lactose is necessary for lactobacilli to colonize in the digestive tract. One-half of the pigs received a $10-\mathrm{ml}$ inoculum daily for 2 weeks via stomach tubes. Two inocula were used: water (control) and $L$. acidopbilus (LA) culture strain DDS $1(2 \times$ $10^{11}$ viable cells $\left./ \mathrm{ml}\right)$. The pigs that did not receive an inoculum were assigned to a diet with or without Probios ( $4 \times 10^{6}$ viable cells $/ \mathrm{g}$ ), a LA feed additive. The experimental treatments were: (1) control, (2) Probios, (3) water inoculum, (4) acidophilus inoculum, (5) lactose + Probios, (7) lactose + water inoculum and (8) lactose + acidophilus inoculum. Gain and feed conversion were not significantly affected by treatments. There was a trend toward improved average daily gain (ADG) with lactose and Probios. The water inoculation reduced ADG by $14.4 \%$ in relation to the performance of pigs receiving the other diets. This reduction in ADG appeared to be related to the extrinsic stress caused by the inoculation process. Also, the stress of the inoculation affected fecal flora by reducing lactobacilli $(\mathrm{P}<.05)$ and increasing coliforms $(\mathrm{P}<.05) . L$. acidopbilus inoculum improved ADG (11.0\%) and feed conversion $(1.5 \%)$. Although the probiotic
\end{abstract}

\footnotetext{
'Published as paper no. 5879, Journal Ser., Nebraska Agri. Exp. Sta.

${ }^{2}$ Dep. of Anim. Sci. Acknowledgement is made to Debbie Koester and Alice Teter for their assistance in preparation of the manuscript.
}

products tended to improve ADG (7.2\%), LA therapy may have been a function of the dietary carbohydrate source. The LA inoculum increased $(\mathrm{P}<.05)$ fecal lactobacillus counts. After the daily inocula were discontinued, an increase in lactobacilli was observed for the water-inoculated group, and a decrease in lactobacilli was noted for the microbe-inoculated group. Pigs receiving lactose in combination with the lactobacillus inoculum had the highest lactobacillus counts and the best ADG. Probios did not affect $(P>.05)$ fecal lactobacillus counts. Neither $L$ acidophilus inoculum nor Probios was effective $(P>.05)$ in suppressing $E$. coli. Lactobacillus treatments did not affect $(P>.05)$ red or white blood cell counts, serum proteins (albumin and globulin) or blood urea nitrogen.

(Key Words: Swine, Probiotics, L. acidopbilus, Probios, Lactose.)

\section{Introduction}

It has been shown that weaning can cause changes in gastric function that accelerate the growth of $E$. coli, a normal bacterial inhabitant of the digestive tract that increases in numbers during diarrhea (Schulman, 1973). Several researchers (Muralidhara et al., 1977; Mitchell and Kenworthy, 1976; Hill et al., 1970 a,b; Porter and Kenworthy, 1969; Moon, 1975) have shown that lactobacilli suppress hemolytic coliforms, which may be an integral part of postweaning lag, commonly observed in nurseries in swine production.

Lactobacillus therapy has been shown to help improve gain and feed efficiency of poultry (Tortuero, 1973; Fuller and Brooker, 1974) and swine (Parker, 1975; Baird, 1977; Hale and Newton, 1979). Other researchers (Hines and Koch, 1971; Mahan and Newland, 1976; Cline et al., 1976; Holden, 1976) have observed no response in swine, and the value of lactobacillus products has not been fully 638

elucidated. Gordon et al. (1957) sugggested 
that the efficacy of the product may be re lated to the extent of viability of concentrate or dried preparation of lactobacilli. Donaldson (1964) and Hawley et al. (1959) suggested that large quantities of lactose are necessary for lactobacilli to establish themselves in the gut.

The objective of this study was to determine the effect of viable cultures of LA in lactose supplemented starter diets on performance, fecal lactobacillus and coliform counts, hematology and serum proteins of young pigs.

\section{Experimental Procedure}

Seventy-two crossbred pigs (average initial weight $6 \mathrm{~kg}$ ) were blocked on the basis of initial weight and then allotted at random to eight dietary treatments in a $2 \times 4$ factorial arrangement of treatments. The pigs were housed in 24 pens (three animals per pen) in an environmentally regulated nursery. Three pens were assigned to each dietary treatment.

The nonmedicated experimental diets (table 1) were corn-soybean meal ( $18 \%$ crude protein) diets with two levels of lactose ( 0 and $10 \%$ ). Lactose was substituted in the diet for an equal weight of starch. One-half of the pigs received a $10-\mathrm{ml}$ inoculum daily for 2 weeks via stomach tubes. Two inocula were used: water and a commercial LA culture ${ }^{3}$ (strain DDS 1), which was isolated originally from milk products. The frozen acidophilus culture was thawed in lukewarm water for $1 \mathrm{hr}$ prior to inoculation. The lactobacillus population of the culture was determined to have approximately $2 \times$ $10^{11}$ viable cells $/ \mathrm{ml}$. The water inoculation was given to equalize across treatments the amount of stress due to the inoculation procedure. The pigs that did not receive an inoculum were assigned to a diet with or without Probios ${ }^{4}$. The lactobacillus population of Probios, as determined with LBS agar $^{5}$, a medium selective for $L$. acidopbilus, was $4 \times 10^{6}$ viable cells/g of Probios. Probios was stored in a refrigerator

\footnotetext{
${ }^{3}$ Acidophilus culture, Great Lakes Biochemical Co., Milwaukee, WI.

${ }^{4}$ NuLabs Division, Pioneer Hi-Bred International, Portland, OR.

${ }^{5}$ LBS agar, BBL, Division of Becton-Dickinson Co., Cockeysville, MD.

${ }^{6}$ Vacutainer tubes, Becton-Dickinson, Rutherford, $\mathrm{NJ}$.

${ }^{7}$ Sigma Tech. Bull. No. 630, Sigma Chemical Co., St. Louis, MO.
}

TABLE 1. COMPOSITION OF DIETS

\begin{tabular}{llcc}
\hline & & \multicolumn{2}{c}{$\%$ Lactose $^{\mathrm{a}}$} \\
\cline { 3 - 4 } Ingredient, \% & $\begin{array}{l}\text { Internat'l. } \\
\text { Ref. No. }\end{array}$ & 0 & 10 \\
\hline Corn, yellow, ground & $4-02-931$ & 44.65 & 44.65 \\
Soybean meal & $5-04-604$ & 29.02 & 29.02 \\
Oats, ground & $4-03-309$ & 10.00 & 10.00 \\
Starch & & 10.00 & $\ldots .00$ \\
Lactose & &.. & 10.00 \\
Lard & $4-00-409$ & 2.50 & 2.50 \\
Dicalcium phosphate & $6-01-080$ & 1.63 & 1.63 \\
Limestone, ground & $6-02-632$ & .60 & .60 \\
Premix b & & 1.60 & 1.60 \\
& & &
\end{tabular}

${ }^{a}$ Calculated analysis: crude protein, $18 \%$; lysine, $.99 \% ; \mathrm{Ca}, .70 \% ; \mathrm{P}, .65 \%$.

$\mathrm{b}_{\text {Premix consisted of } .5 \% \text { iodized salt, } .1 \% \text { trace }}$ mineral mix and $1.0 \%$ vitamin $\mathrm{mix}$ in a finely ground corn carrier. Vitamin mix provided (per $\mathrm{kg}$ ) diet: vita min $A, 3,307$ IU; vitamin $D_{3}, 441 \mathrm{IU}$; vitamin $\mathrm{E}, 22$ IU; menadione sodium bisulfite, $2.2 \mathrm{mg}$; riboflavin, $2.2 \mathrm{mg}$; d-pantothenic acid, $13.2 \mathrm{mg}$; niacin, $17.6 \mathrm{mg}$; choline chloride, $110.2 \mathrm{mg}$; vitamin $B_{12}, 22 \mathrm{mcg}$; ethoxyquin, $4.4 \mathrm{mg}$. Trace mineral mix provided (milligrams/kilogram) of diet: $\mathrm{Zn}, 100 ; \mathrm{Fe}, 50 ; \mathrm{Mn}$, $27.5 ; \mathrm{Cu}, 5 ; \mathrm{Co}, .5 ; \mathrm{I}, .75$.

before being added to the basal diets on a biweekly basis. The experimental treatments were: (1) control, (2) Probios, (3) water inoculum, (4) acidophilus inoculum, (5) lactose, (6) lactose + Probios, (7) lactose + water inoculum and (8) lactose + acidophilus inoculum.

Pigs were weighed and feed intake was recorded weekly for 28 days. Blood samples were taken from each pig $0,4,7$ and 14 days after the initiation of the trial for red and white blood cell counts. Blood was collected into evacuated glass tubes ${ }^{6}$ containing sodium fluoride and EDTA. Blood cell counts were performed by conventional methods. Blood samples were also obtained 7 and 21 days after initiation of the study for determination of urea nitrogen and serum proteins (albumin and globulin). After centrifugation, the serum was transferred to sterile plastic culture tubes, sealed and frozen at $-10 \mathrm{C}$ until analyzed. Total serum protein was determined by the Lowry method with Folin-Ciocalteau reagent (Lowry et al., 1951). Serum albumin was determined by a colorimetric procedure ${ }^{7}$ available commercially. Serum globulin was estimated as the difference between total protein and albumin. Urea nitrogen determinations were completed with an automated system described by Frankel (1970). 
At the end of each week, a fresh fecal sample was taken from each pig and placed in a sterile plastic bag. The samples were pooled by pen and an aliquot of approximately $1 \mathrm{~g}$ was placed in $100 \mathrm{ml}$ of sterile phosphate buffer. The samples were diluted in 100-fold steps for enumeration of LA (LBS agar) and coliforms $\left(V_{R B A}{ }^{8}\right)$ by the pour plate method. LBS plates were incubated for $72 \mathrm{hr}$ at $35 \mathrm{C}$ in an anaerobic incubator with $\mathrm{CO}_{2}$, and VRBA plates were incubated aerobically for $24 \mathrm{hr}$ at $35 \mathrm{C}$ using duplicate samples. Petri dishes that had 30 to 300 colonies were counted.

Data were analyzed by standard analysis of variance procedures (Barr et al., 1976). Orthogonal contrasts were used to compare treatment means, and correlation coefficients were calculated to compare parameters (Snedecor and Cochran, 1967).

\section{Results and Discussion}

Gains and feed conversion were not significantly affected by treatments (table 2). There was a trend toward improved average daily gain (ADG) with lactose and Probios. The water inoculation reduced ADG by $14.4 \%$. Reduction in ADG appeared to be related to the extrinsic stress caused by handling of the pigs for the MI.

${ }^{8}$ Violet Red Bile Agar, Difco Laboratories, Detroit, daily inoculation. The LA inoculum improved ADG (11.0\%) and feed conversion (FC) $(1.5 \%)$. The dried probiotic (Probios) appeared to increase ADG slightly over that for the acidophilus-inoculated group (.214 vs $.201 \mathrm{~kg})$. However, the greatest gain was observed $(.225 \mathrm{~kg})$ when acidophilus inoculum was given in combination with the $10 \%$ lactose diet. It appeared that the LA activity was dependent upon the dietary carbohydrate source.

The effect of LA products on fecal lactobacilli and coliforms is summarized in table 3. The water inoculum decreased $(\mathrm{P}<.05)$ lactobacillus counts and increased $(P<.05)$ coliform counts. Several researchers (Tannock and Savage, 1974; Kenworthy and Crabb, 1963; Schulman, 1973) have observed decreased lactobacilli and increased coliforms when animals have been subjected to adverse dietary and environmental conditions, such as weaning, diet change and transporting. The alternating of fecal flora may explain the $14 \%$ decrease in gain due to the inoculation procedure.

The LA inoculum increased $(P<.05)$ fecal lactobacillus counts. While the pigs were receiving the daily acidophilus inoculum, their lactobacillus counts were substantially higher than those for the water-inoculated group (figure 1). When the daily inocula were terminated, an increase in lactobacilli was observed for the control group, while lactobacillus counts for the treated animals decreased.

TABLE 2. EFFECT OF $L$. ACIDOPHILUS ON GAINS AND FEED CONVERSION OF BABY PIGS FED A STARTER DIET SUPPLEMENTED WITH LACTOSE ${ }^{a}$

\begin{tabular}{|c|c|c|c|c|c|c|c|}
\hline \multirow[b]{3}{*}{ Item } & \multirow{3}{*}{$\begin{array}{c}\text { Lactose, } \\
\%\end{array}$} & \multicolumn{5}{|c|}{ Treatment } & \multirow[b]{3}{*}{ Avg } \\
\hline & & \multicolumn{3}{|c|}{ No inoculum } & \multicolumn{2}{|c|}{ Inoculated } & \\
\hline & & & None & Probios ${ }^{b}$ & Water & Acidophilus ${ }^{\mathrm{c}}$ & \\
\hline \multirow[t]{2}{*}{ ADG, $\mathrm{kg}$} & $\begin{array}{r}0 \\
10\end{array}$ & & $\begin{array}{l}.199 \\
.214\end{array}$ & $\begin{array}{l}.215 \\
.213\end{array}$ & $\begin{array}{l}.195 \\
.166\end{array}$ & $\begin{array}{l}.176 \\
.225\end{array}$ & $\begin{array}{l}.196 \\
.205\end{array}$ \\
\hline & & Avg & .207 & .214 & .181 & .201 & \\
\hline \multirow[t]{2}{*}{ FC } & $\begin{array}{r}0 \\
10\end{array}$ & & $\begin{array}{l}2.16 \\
1.91\end{array}$ & $\begin{array}{l}2.09 \\
2.04\end{array}$ & $\begin{array}{l}1.88 \\
2.07\end{array}$ & $\begin{array}{l}1.92 \\
1.98\end{array}$ & $\begin{array}{l}2.01 \\
2.00\end{array}$ \\
\hline & & Avg & 2.04 & 2.07 & 1.98 & 1.95 & \\
\hline
\end{tabular}

${ }_{72}$ crossbred pigs (three pigs per treatment; three replications). Average initial weight, 6 kilograms. Length of study, 28 days.

${ }^{b}$ Lactobacillus product (NuLabs); use rate $=1 \mathrm{~g} / \mathrm{kg} \mathrm{diet;} 4 \times 10^{6}$ organisms $/ \mathrm{g}$.

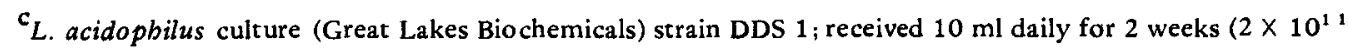
organisms $/ \mathrm{ml}$ ). 
TABLE 3. EFFECT OF L. ACIDOPHILUS ON FECAL COUNTS OF BABY PIGS FED A STARTER DIET SUPPLEMENTED WITH LACTOSE ${ }^{\mathrm{a}}$

\begin{tabular}{|c|c|c|c|c|c|c|c|}
\hline \multirow[b]{3}{*}{ Item } & \multirow{3}{*}{$\begin{array}{c}\text { Lactose } \\
\%\end{array}$} & \multicolumn{5}{|c|}{ Treatment } & \multirow[b]{3}{*}{ Avg } \\
\hline & & \multicolumn{3}{|c|}{ No inoculum } & \multicolumn{2}{|c|}{ Inoculated } & \\
\hline & & & None & Probios $^{6}$ & Water & Acidophilus & \\
\hline \multirow[t]{3}{*}{ L. acidopbilus ${ }^{\mathrm{efg}}$} & 0 & & 8.08 & 8.05 & 7.43 & 7.83 & 7.85 \\
\hline & 10 & & 8.04 & 8.31 & 7.60 & 8.16 & 8.03 \\
\hline & & Avg & 8.06 & 8.18 & 7.52 & 8.00 & \\
\hline \multirow[t]{3}{*}{ Coliforms $^{\mathrm{e}}$} & 0 & & 7.46 & 7.74 & 8.03 & 7.97 & 7.80 \\
\hline & 10 & & 7.38 & 7.79 & 7.80 & 8.10 & 7.77 \\
\hline & & $A v g$ & 7.42 & 7.77 & 7.92 & 8.04 & \\
\hline
\end{tabular}

${ }^{a}$ Each value represents 36 observations (four time periods, three pens, three pigs per pen).

${ }^{b_{L}}$ actobacillus product (NuLabs); use rate $=1 \mathrm{~g} / \mathrm{kg}$ diet; fed culture continuously.

$c_{L}$. acidophilus (Great Lakes Biochemicals) strain DDS 1 ; received $10 \mathrm{ml}$ daily for 2 weeks.

${ }^{\mathrm{d}} \mathrm{CFU}=$ colony forming units.

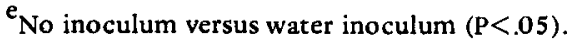

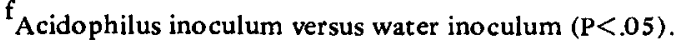

$\mathbf{g}_{\mathrm{Probios}}+$ acidophilus inoculum versus no probios + water inoculum $(\mathrm{P}<.05)$.

After termination of daily inocula, the treated group had a slightly higher LA population, which might suggest possible colonization

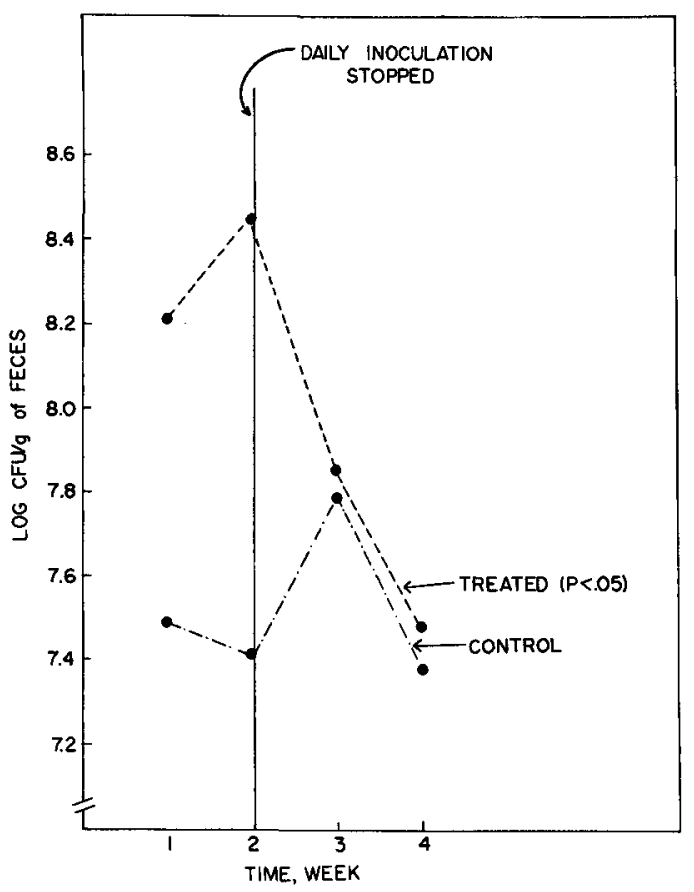

Figure 1. Effect of $L$. Acidopbilus inoculum on lactobacillus fecal counts of starter pigs. in the digestive tract.

The validity of fecal lactobacillus counts as an indicator of colonization in the tract is questionable. Pollmann et al. (1980), in a study of both gnotobiotic and conventional pigs, found no significant correlations between seven digestive tract locations (stomach, small and

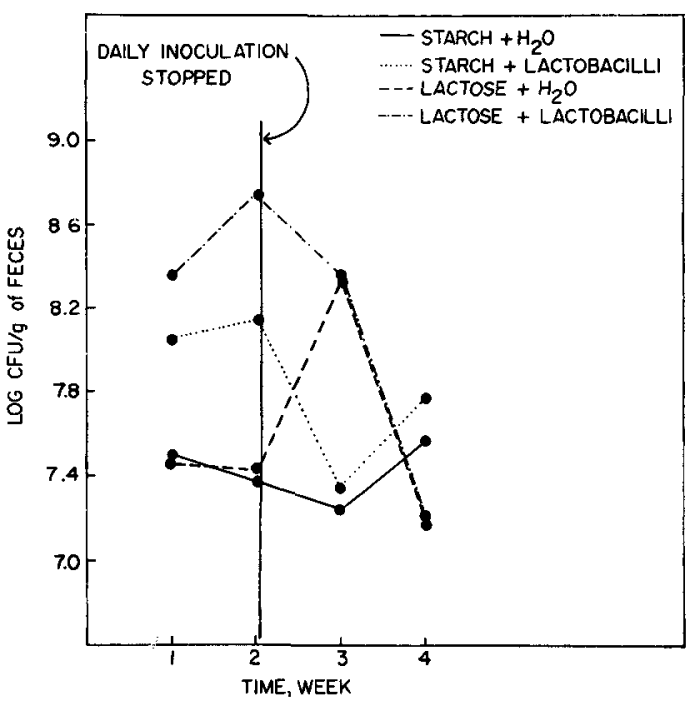

Figve 2. Effect of L. Acidophilus inoculum on fecal 'dc sbacillus counts of starter pigs fed a diet supp' :r =nted with lactose. 


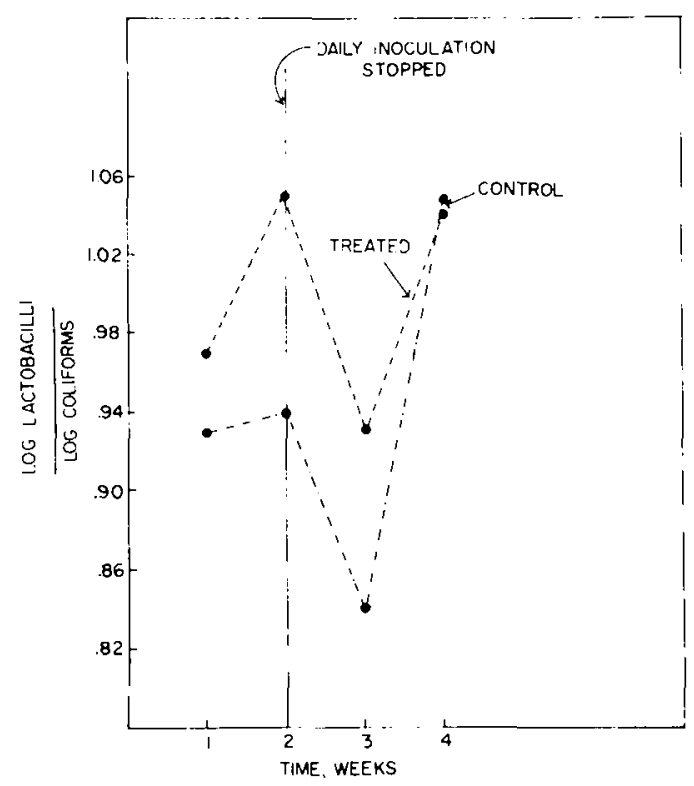

Figure 3. Effect of L. Acidopbilus inoculum in starter pigs on coliform fecal counts.

large intestine) and fecal lactobacilli or coliforms.

The possible effect of lactose on fecal lactobacillus counts is illustrated in figure 2 . Donald son (1964) and Hawley et al. (1959) suggested that large quantities of lactose are necessary for lactobacilli to become established in the gut. It is evident (figure 2) that pigs receiving lactose in combination with the lactobacillus inoculum had the highest lactobacillus counts. After the daily inocula were discontinued, both groups of animals receiving lactose treatments had similar lactobacillus counts.

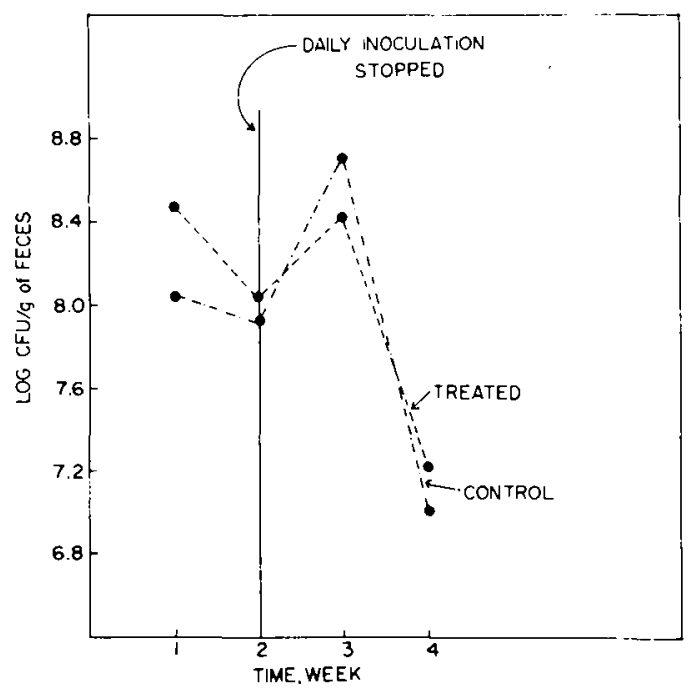

Figure 4. Effect of $L$. Acidophilus inoculum in starter pigs on lactobacillus to coliform ratio.

The LA inoculum was not effective ( $\mathrm{P}>.05)$ in suppressing $E$, coli (figure 3 ), contrary to results reported by several researchers (Muralid hara et al., 1977; Mitchell and Kenworthy, 1976; Hill et al., 1970a,b; Porter and Kenworthy, 1969). A negative correlation ( $\mathrm{r}=$ -.51) between ADG and coliform counts $(P<.05)$ was observed, which suggests possible hazards of an increase in coliform population. Muralidhara et al. (1977) proposed a relationship between lactobacilli (L) and coliforms (C) by expressing the data as a lactobacilli to coliform ratio ( $\mathrm{L}: \mathrm{C}$ ). He suggested that the higher the $\mathrm{L}: \mathrm{C}$ ratio is, the better the microflora contribution to growth performance of host. The L:C ratio (figure 4) was higher for

TABLE 4. EFFECT OF L. ACIDOPHILUS ON HEMATOLOGY OF BABY PIGS FED A STARTER DIET SUPPLEMENTED WITH LACTOSE ${ }^{2}$

\begin{tabular}{|c|c|c|c|c|c|c|c|}
\hline \multirow[b]{3}{*}{ Item } & \multirow{3}{*}{$\begin{array}{c}\text { Lactose, } \\
\%\end{array}$} & \multicolumn{5}{|c|}{ Treatment } & \multirow[b]{3}{*}{ Avg } \\
\hline & & \multicolumn{3}{|c|}{ No inoculum } & \multicolumn{2}{|c|}{ Inoculated } & \\
\hline & & & None & Probios & Water & Acidophilus & \\
\hline \multirow[t]{2}{*}{$\mathrm{RBC}^{\mathrm{b}}, 10^{6} / \mathrm{mm}^{3}$} & $\begin{array}{r}0 \\
10\end{array}$ & & $\begin{array}{l}5.75 \\
6.02\end{array}$ & $\begin{array}{l}5.71 \\
5.73\end{array}$ & $\begin{array}{l}5.98 \\
5.56\end{array}$ & $\begin{array}{l}5.89 \\
5.71\end{array}$ & $\begin{array}{l}5.83 \\
5.76\end{array}$ \\
\hline & & Avg & 5.89 & 5.72 & 5.77 & 5.80 & \\
\hline \multirow[t]{2}{*}{$\mathrm{WBC}, 10^{3} / \mathrm{mm}^{3}$} & $\begin{array}{r}0 \\
10\end{array}$ & & $\begin{array}{l}15.79 \\
17.69\end{array}$ & $\begin{array}{l}16.67 \\
20.56\end{array}$ & $\begin{array}{l}15.44 \\
20.89\end{array}$ & $\begin{array}{l}19.69 \\
14.92\end{array}$ & $\begin{array}{l}16.90 \\
18.03\end{array}$ \\
\hline & & Avg & 16.74 & 18.62 & 18.17 & 17.31 & \\
\hline
\end{tabular}

\footnotetext{
${ }^{a}$ Each value represents 36 observations (four time periods, three pens, three pigs per pen).

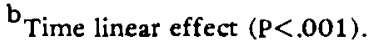


TABLE 5. EFFECT OF L. ACIDOPHILUS ON SERUM PROTEINS OF BABY PIGS FED A STARTER DIET SUPPLEMENTED WITH LACTOSE ${ }^{\text {a }}$

\begin{tabular}{|c|c|c|c|c|c|c|c|}
\hline \multirow[b]{3}{*}{ Item $^{b}$} & \multirow{3}{*}{$\begin{array}{c}\text { Lactose, } \\
\%\end{array}$} & \multicolumn{5}{|c|}{ Treatment } & \multirow[b]{3}{*}{ Avg } \\
\hline & & \multicolumn{3}{|c|}{ No inoculum } & \multicolumn{2}{|c|}{ Inoculated } & \\
\hline & & & None & Probios & Water & Acidophilus & \\
\hline \multirow[t]{3}{*}{ Urea nitrogen } & 0 & & 12.78 & 13.13 & 12.57 & 12.58 & 12.77 \\
\hline & 10 & & 12.70 & 12.10 & 11.72 & 11.92 & 12.11 \\
\hline & & Avg & 12.74 & 12.62 & 12.15 & 12.25 & \\
\hline \multirow[t]{3}{*}{ Total protein } & 0 & & 5.69 & 5.34 & 5.48 & 4.95 & 5.37 \\
\hline & 10 & & 4.47 & 4.58 & 5.53 & 5.10 & 4.92 \\
\hline & & Avg & 5.08 & 4.96 & 5.51 & 5.03 & \\
\hline \multirow[t]{3}{*}{ Albumin $^{c}$} & 0 & & 2.55 & 2.66 & 2.78 & 2.66 & 2.66 \\
\hline & 10 & & 2.69 & 2.60 & 2.73 & 2.81 & 2.71 \\
\hline & & Avg & 2.62 & 2.63 & 2.76 & 2.74 & \\
\hline \multirow[t]{3}{*}{ Globulin ${ }^{c}$} & 0 & & 3.14 & 2.68 & 2.70 & 2.29 & 2.70 \\
\hline & 10 & & 2.07 & 1.99 & 2.81 & 2.29 & 2.29 \\
\hline & & Avg & 2.61 & 2.34 & 2.76 & 2.29 & \\
\hline
\end{tabular}

${ }^{a}$ Each value represents 18 observations (two time periods, three pens, three pigs per pen).

${ }^{\mathrm{b}}$ Milligrams/100 milliliters.

$\mathrm{c}_{\text {Time effect }}(\mathrm{P}<.01)$.

the acidophilus-inoculated group than for the water-inoculated group. Two weeks after termination of the daily inocula, the $\mathrm{L}: \mathrm{C}$ ratios were similar for the treated and control groups. These data suggest that a daily source of lactobacilli is necessary to maintain increased fecal lactobacilli and higher $\mathrm{L}: \mathrm{C}$ ratios.

Although the Probios did not significantly affect fecal lactobacillus or coliform counts, a slight increase in lactobacilli (8.05 vs 8.31) was observed in the lactose-supplemented group. Probios also tended to increase fecal coliforms ( 7.42 vs 7.77 ). This observation conflicts with the report of Moon (1975), who found that Probios was effective in suppressing $E$, coli.

The lactobacillus treatments did not significantly affect hematology (table 4). As expected, red blood cell counts increased $(\mathrm{P}<.001)$ linearly as the pigs matured, but no dietary effects were observed. White blood cells were not significantly affected. Wagner (1959) and Pollmann et al. (1980) observed increased leukocytic activity in gnotobiotic animals inoculated with lactobacilli, which suggests that lactobacilli may be involved in the immune response of conventional animals as well as gnotobiotes.

Serum proteins and urea nitrogen were not affected $(\mathrm{P}<.05)$ by dietary treatment (table 5$)$.
A time effect was observed $(\mathrm{P}<.01)$ for albumin and globulin regardless of treatment. Albumin levels were higher $(\mathrm{P}<.01)$ at the first bleeding than at the second, while globulin levels were higher $(P<.01)$ at the second bleeding than at the first. Albumin to globulin ratios were near normal. Significant correlations were observed between serum albumin levels and ADG ( $r=$ .54) and between serum globulin levels and FC $(\mathrm{r}=.51)$.

\section{Literature Cited}

Baird, D. M. 1977. Probiotics help boost feed efficiency. Feedstuffs 49 (Sept. 11): 11 .

Barr, A. J., J. H. Goodnight, J. P. Sall and J. T. Helwig. 1976. A user's guide to SAS-76. SAS Institute Inc., Raleigh, NC.

Cline, T. R., D. Forsyth and M. P. Plumlee. 1976. Probios for starter and grower pigs. Purdue Swine Day Rep. p. 53.

Donaldson, R. M. 1964. Normal bacteria populations of the intestine and their relationship to intestinal function. New England J. Med. 270:994.

Frankel, S. 1970. Nitrogen. In S. Frankel, S. Reitman, and A. C. Sonnerwirth (Ed.) Gradwohl's Clinical Laboratory Methods and Diagnosis (7th Ed.). C. V. Mosby Co., New York.

Fuller, R. and B. E. Brooker. 1974. Lactobacilli which attach to the crop epithelium of the fowl. Amer. J. Clin. Nutr. 27:1305.

Gordon, D., J. MacRae and D. M. Wheater. 1957. Lactobacillus preparation for use with antibiotics. Lancet 272:899. 
Hale, O. M. and G. L. Newton. 1979. Effects of a nonviable Lactobacillus species fermentation product on performance of pigs. J. Anim. Sci. 48:770.

Hawley, H. B., P. A. Shepherd and D. M. Wheater. 1959. Factors affecting implantation of lactobacilli in the intestine. J. Appl. Bacteriol. 22 : 360.

Hill, I. R., R. Kenworthy and P. Porter. 1970a. Studies of the effect of dietary lactobacilli on intestinal and urinary amines in pigs in relation to weaning and post-weaning diarrhea. Res. Vet. Sci. 11: 320.

Hill, I. R., R. Kenworthy and P. Porter. 1970b. The effect of dietary lactobacilli on in vitro catabolic activities of the small intestinal microflora on newly weaned pigs. J. Med. Microbiol. 3:593.

Hines, R. H. and B. A. Koch. 1971. Response of growing and finishing swine to dietary source of Lactobacillus acidopbilus. Kansas Agr. Exp. Sta. Prog. Rep. $181: 29,32$.

Holden, P. J. 1976. The effect of commercial feed additives on the performance of early-weaned pigs. Proc. Internat'l Pig Vet. Soc. AA5.

Kenworthy, R. and W. E. Crabb. 1963. The intestinal flora of young pigs with reference to early weaning Escherichai coli and scours. J. Comp. Pathol. $73: 215$.

Lowry, O. H., N. J. Rosebrough, A. L. Farr and R. T. Randall. 1951. Protein measurements with folin phenol reagent. J. Biol. Chem. 193:256.

Mahan, D. C. and H. W. Newland. 1976. Short term effects of the addition of oats, bacterial cultures (Probiotic), and antibiotics to the diets of weaned pigs. Ohio Agr. Res. Bull., p. 35.

Mitchell, I. De G. and R. Kenworthy. 1976. Investiga tions on a metabolite from Lactobacillus bulgaricus which neutralizes the effect of enterotoxin from Escbericbia coli pathogenic for pigs.
J. Appl. Bacteriol. $41: 163$.

Moon, H. W. 1975. An evaluation of the evidence of preventative or therapeutic effects of lactobacilli in enteric $E$. coli infection of swine. Amer. Feed Manufacturers Assoc. Nutr. Council, November, P.42.

Muralidhara, K. S., G. G. Sheggeby, P. R. Elliker, D. C. England and W. E. Sandine. 1977. Effect of feed ing lactobacilli on the coliform and lactobacillus flora of intestinal tissue and feces from piglets. J. Food Protection 40:288.

Parker, R. B. 1975. Applications of lactobacillus feed ing in swine and other livestock. Amer. Feed Manufacturers Assoc. Nutr. Council, November, p. 38.

Pollmann, D. S., D. M. Danielson, W. B. Wren, E. R. Peo, Jr. and K. M. Shahani. 1980. Influence of Lactobacillus acidopbilus inoculum in gnotobiotic and conventional pigs. J. Anim. Sci. 51: 629.

Porter, P. and R. Kenworthy. 1969. A study of intestinal and urinary amines in pigs in relation to weaning. Res. Vet. Sci. 10:440.

Schulman, A. 1973. Effect of weaning on pH changes of the contents of the piglet's stomach and duodenum. Nord. Vet. Med. 25:220.

Snedecor, G. S. and S. G. Cochran. 1967. Statistical Methods (6th Ed.). The lowa State Univ. Press, Ames, IA.

Tannock, G. W. and D. C. Savage. 1974. Microbial interference between indigenous yeast and lactobacilli in the rodent stomach. J. Bacteriol. 98:1278.

Tortuero, F, 1973. Influence of the implantation of Lactobacillus acidophilus in chicks on growth, feed conversion, malabsorption of fat syndrome and intestinal flora. Poul. Sci. 52:197.

Wagner, M. 1959. Serologic aspects of germ-free life. Ann. NY Acad. Sci. 78:261. 